KAWISTARA

VOLUME 5

No. 3, 22 Desember 2015

Halaman 221-328

\title{
ARAHAN PENGEMBANGAN OBYEK WISATA MENUJU PEMBANGUNAN PARIWISATA BERKELANJUTAN DI KABUPATEN WONOGIRI
}

\author{
Joko Wuri Nugroho, Komarsa Gandasasmita, dan Manuwoto \\ Badan Perencanaan Pembangunan Daerah Kabupaten Wonogiri \\ Email: jokobappedawonogiri007@gmail.com
}

\begin{abstract}
The development of the tourism sector in Wonogiri Regency is still more left behind than Pacitan Regency and Gunungkidul Regency. This problem may possibility by the weakness in the policy from Wonogiri Regency Government. Thus, we need research which have purposes : (1) to know economic development in Wonogiri Regency (2) to know tourism objects which have potential amendable, (3) to know efficiency from tourism objects management, and (3) formulate direction and strategies development of potential tourism object for sustainable development. Spot of the research in 40 tourism objects with survey and interview respondent. Analysis data use entropi method, scoring method, description method, DEA method, AHP method, IFAS method, EFAS method, Matrix IE method, Matrix Space method and A'WOT method. The results show five county with best economic development are Wonogiri, Ngadirojo, Pracimantoro, Jatisrono and Baturetno; there five tourism objects with potentially classification to develop are Setren Girimanik, Sendang Asri, Karamba Cakaran, Puppet Tourism Village Kepuhsari and Karst Museum; Tourism objects with efficient management are Setren Girimanik, Sendang Asri and Karst Museum; Tourism management from Gunungkidul Regency can adapt in Wonogiri Regency; Priority strategies which recommended are make four tourism region and increasing tourism objects accessibility.
\end{abstract}

Keywords: Tourism potential; Strategies; Sustainable development

\begin{abstract}
ABSTRAK
Perkembangan pariwisata Kabupaten Wonogiri ternyata tertinggal dibandingkan Kabupaten Pacitan dan Kabupaten Gunungkidul. Hal ini dimungkinkan karena kelemahan dalam kebijakan kepariwisataan yang dijalankan Pemerintah Kabupaten Wonogiri. Oleh karena itu diperlukan penelitian yang bertujuan (1) mengetahui perkembangan ekonomi wilayah Kabupaten Wonogiri, (2) mengetahui potensi obyek-obyek wisata yang dimiliki, (3) mengetahui efisiensi pengelolaan obyek wisata yang dikelola, (4) mengetahui perbedaan pengelolaan kepariwisataan Kabupaten Wonogiri, Kabupaten Gunungkidul dan Kabupaten Pacitan serta (5) menentukan strategi yang digunakan serta memberikan arahan pengembangan pariwisata berkelanjutan Kabupaten Wonogiri. Titik penelitian dilakukan terhadap 40 obyek wisata dengan survey diperkuat wawancara responden. Teknik analisis data menggunakan metode entropi, metode skoring, metode deskriptif, metode DEA dan metode AHP,IFAS,EFAS,Matriks IE,Matriks Space serta metode A'WOT. Hasil penelitian menunjukkan 5 (lima) kecamatan dengan perkembangan wilayah terbaik adalah Wonogiri, Ngadirojo, Pracimantoro, Jatisrono dan Baturetno; ada 5 (lima) obyek wisata dengan klasifikasi berpotensi untuk dikembangkan, yaitu : Kawasan Setren Girimanik, Sendang Asri, Karamba Cakaran, Desa Wisata Wayang Kepuhsari dan Museum Karst; Obyek wisata dengan pengelolaan efisien adalah
\end{abstract}


Sendang Asri, Setren Girimanik dan Museum Karst; pengelolaan kepariwisataan Kabupaten Gunungkidul lebih ideal untuk diadopsi, Strategi utama yang direkomendasikan adalah pembuatan 4 (empat) kawasan wisata serta peningkatan aksesibilitas obyek wisata.

Kata Kunci: Potensi wisata; Strategi; Pembangunan berkelanjutan.

\section{PENGANTAR}

Pariwisata telah terbukti berpengaruh positif terhadap perekonomian sebuah negara yang didapatkan dari pendapatan nilai tukar valuta asing, penerimaan devisa akibat adanya konsumsi wisatawan, penyerapan tenaga kerja, pembangunan infrastruktur pariwisata yang turut dinikmati oleh masyarakat lokal, dan beberapa destinasi pariwisata juga sebagai generator pemberdayaan perekonomian masyarakat lokal (Kurniawati, 2013).

Sumbangan sektor pariwisata yang signifikan terhadap pendapatan daerah merupakan harapan yang ingin diwujudkan daerah-daerah lainnya di Indonesia termasuk 3 (tiga) kabupaten yang memiliki keunikan bentang alam karst sehingga memiliki potensi wisata pantai dan goa yang besar, yaitu Kabupaten Wonogiri, Kabupaten Gunungkidul dan Kabupaten Pacitan. Data statistik kepariwisataan menunjukkan bahwa Kabupaten Wonogiri dalam posisi tertinggal dibandingkan kabupaten tetangga tersebut. Selama tahun 2012 jumlah wisatawan yang berkunjung ke Kabupaten Pacitan sebanyak 654.651 orang. Kabupaten Gunung Kidul dengan jumlah wisatawan 1.279.065 orang menyumbangkan Rp 3.620.669.200,00 dari retribusi obyek wisata serta keseluruhan subsektor pariwisata sebesar Rp 8.478. 767.500,00 (12,64\%) terhadap PAD tahun 2012. Adapun Kabupaten Wonogiri dengan jumlah wisatawan 578.843 orang menyumbangkan Rp2.825.343.000,00 dari retribusi obyek wisata serta keseluruhan subsektor pariwisata sebesar Rp 3.604.481.000,00 (3,60\%) terhadap PAD tahun 2012.

Keadaan tersebut tentu kurang ideal mengingat Kabupaten Wonogiri juga memiliki potensi wisata waduk dan wisata pegunungan. Pemerintah Daerah Kabupaten Wonogiri telah berusaha mengembangkan kepariwisataannya dengan desain strategi pembangunan pariwisata daerah sebagaimana tercantum dalam Rencana Induk Pengembangan Pariwisata Daerah (RIPPDA) Kabupaten Wonogiri Tahun 2004 - 2014 yang meliputi: (1) Pengembangan produk wisata yang mengarah pada tema "berwisata di alam bersama keluarga"; (2) Pengembangan keanekaragaman produk wisata dan harga; (3) Pemanfaatan teknologi informasi bagi promosi dan informasi pariwisata Kabupaten Wonogiri; (4) Pengembangan citra pariwisata Kabupaten Wonogiri (image development); (5) Eksplorasi pasar potensial dan pemeliharaan pasar yang telah ada; (6) Meningkatkan peran serta sektor swasta dan masyarakat dalam pengelolaan pariwisata; (7) Meningkatkan fungsi koordinasi pengelolaan pariwisata Kabupaten Wonogiri; (8) Meningkatkan kualitas pendidikan khusus kepariwisataan; (9) Meningkatkan daya tarik bekerja di sektor pariwisata Kabupaten Wonogiri; serta (10) Pengembangan investasi sarana dan prasarana publik pada lokasi dan jalur prioritas sesuai dengan kebutuhan.

Kebijakan Kepariwisataan Kabupaten Wonogiri sebenarnya cukup baik, tetapi belum diterapkan secara spesifik. Aspekaspek pembangunan berkelanjutan belum diintegrasikan secara optimal dan kemungkinan inilah yang menjadi perbedaan dengan strategi yang diterapkan Kabupaten Gunungkidul dan Kabupaten Pacitan. Kurniawati (2013) menjelaskan beberapa prinsip yang menjadi acuan pengembangan pariwisata berkelanjutan (sustainable tourism development) terdiri dari: (1) Pembangunan pariwisata harus dibangun dengan melibatkan masyarakat lokal, dengan ide yang melibatkan masyarakat lokal juga dan untuk kesejahteraan masyarakat local; (2) Pembangunan pariwisata harus mampu menjamin keberlanjutan, memberikan keuntungan bagi masyarakat saat ini dan tidak merugikan generasi yang akan dating; (3) Pariwisata harus bertumbuh dalam prinsip 
optimalisasi bukan eksploitasi. Efisiensi pengelolaan obyek wisata perlu diperhatikan.

Pemilihan obyek wisata yang mendapat prioritas untuk dikembangkan seharusnya memperhitungkan aspek ekonomi wilayah, aspek social dan aspek lingkungan. Suatu obyek wisata yang berada atau dekat dengan wilayah berkembang umumnya memiliki aksesibilitas dan sarana prasarana lebih baik dibandingkan obyek wisata pada wilayah belum berkembang. Hal ini sejalan dengan pendapat Fandeli (1995) yang menyatakan bahwa aspek penawaran pariwisata, yaitu (1) Atraksi (daya tarik), maksudnya objek wisata harus mempunyai daya tarik berupa alam atau budaya yang layak dijual ke pasar wisata, (2) Amenitas (fasilitas), maksudnya adalah segala macam fasilitas penunjang perkembangan pariwisata berupa hotel, fasilitas umum, (3) Aksesibilitas (bisa dicapai), maksudnya adalah sarana dan prasarana yang menyebabkan wisatawan dapat mengunjungi objek wisata perlu diperhatikan. Rudita (2012) dalam Tesisnya menemukan bahwa pada Kawasan Agropolitan Payangan Kabupaten Gianyar Provinsi Bali, faktor menonjol yang mempengaruhi kunjungan wisatawan di antaranya pelayanan, jenis wisata dan atraksi yang ditawarkan, fasilitas yang tersedia, sarana transportasi, dan promosi.

Obyek wisata yang berkembang umumnya melibatkan partisipasi aktif masyarakat dalam pengelolaannya. Menurut Conyers (1984 : 154-155), ada tiga alasan utama mengapa partisipasi masyarakat mempunyai sifat sangat penting. Pertama, partisipasi masyarakat merupakan satu alat guna memperoleh informasi mengenai kondisi, kebutuhan dan sikap masyarakat setempat, yang tanpa kehadirannya program pembangunan serta proyek-proyek akan gagal. Kedua, masyarakat akan lebih mempercayai proyek atau program pembangunan jika merasa dilibatkan dalam proses, persiapan dan perencanaannya. Ketiga, timbul anggapan bahwa merupakan suatu hak demokrasi bila masyarakat dilibatkan dalam pembangunan di daerah mereka sendiri.
Obyek wisata didesain sekaligus memiliki fungsi sebagai kawasan lindung. Muhammad et al (2012) dalam artikelnya memperlihatkan pentingnya perpaduan potensi perkembangan wilayah kepariwisataan dengan daya dukung lingkungan kepariwisataan sebagai penyedia jasa lingkungan kepariwisataan. Kondisi daya dukung wilayah yang masih tergolong tinggi dan mempunyai kelenturan memungkinkan untuk lebih dioptimalkan dan tetap berorientasi pada kelestarian fungsi lingkungan yang berkelanjutan.

Pengembangan Kawasan Wisata akan memberikan dampak positif secara keruangan. Menurut Sitorus (2013), kawasan merupakan bagian dari klasifikasi spasial yang meliputi: (1) aspek spatial contiguity dan (2) aspek spatial compactness. wilayah-wilayah yang berkesinambungan secara spasial (spatially contiguous) akan mempermudah pengelolaan. Sebaliknya, wilayah-wilayah yang terpencar atau terfragmentasi (spatially fragmented) akan menciptakan berbagai bentuk inefisiensi. Wilayah-wilayah yang efisien juga ditunjukkan oleh bentuk-bentuk yang kompak (compact). Selain itu, model kawasan wisata yang terintegrasi akan memberikan pilihan obyek yang lebih banyak kepada wisatawan, dapat lebih menonjolkan potensi khas yang dimiliki berupa potensi sumberdaya alam dan tradisi, memudahkan usaha pelestarian mencegah eksploitasi, dan kerusakan lingkungan yang berlebihan serta memudahkan pengelolaannya.

Oleh karena itu, diperlukan penelitian yang bertujuan: (1) mengetahui perkembangan ekonomi wilayah Kabupaten Wonogiri; (2) mengetahui potensi obyek-obyek wisata yang dimiliki Kabupaten Wonogiri; (3) mengetahui efisiensi pengelolaan obyek wisata yang dikelola Pemerintah Daerah; (4) mengetahui perbedaan pengelolaan kepariwisataan Kabupaten Wonogiri, Kabupaten Gunungkidul, dan Kabupaten Pacitan; (5) menentukan strategi yang digunakan serta memberikan arahan pengembangan pariwisata berkelanjutan Kabupaten Wonogiri. 
Titik penelitian dilakukan terhadap 36 obyek wisata Kabupaten Wonogiri, dua obyek wisataKabupatenGunungkiduldanduaobyek wisata Kabupaten Pacitan melalui survey diperkuat wawancara responden. Responden untuk menjawab tujuan kedua sebanyak 28 pamong desa serta 16 orang pamong kecamatan. Responden untuk menjawab tujuan keempat adalah masyarakat sekitar obyek wisata di Kabupaten Gunungkidul dan Kabupaten Pacitan. Responden untuk menjawab tujuan kelima sebanyak 10 orang yang dipandang memiliki wawasan terhadap kondisi kepariwisataan Kabupaten Wonogiri. Teknik analisis data menggunakan Metode Analisis Entropi, Skoring dan Deskriptif, DEA, AHP, IFAS, EFAS, Matriks IE, Matriks Space dan A'WOT. Metode Entropi untuk mengetahui perkembangan ekonomi wilayah Kabupaten Wonogiri berdasarkan data PDRB Tahun 2012. Metode skoring dilakukan dengan menilai potensi suatu obyek wisata terhadap tabel penilaian potensi obyek wisata terbitan Pusat Pariwisata (Puspar) Universitas Gadjah Mada. Metode deskriptif dilakukan untuk menguraikan potensi obyek wisata secara lebih mendalam termasuk pertimbangan hasil pengamatan secara makro terhadap kondisi pariwisata di Kabupaten Gunungkidul dan Kabupaten Pacitan. Metode DEA dipergunakan untuk mengetahui efisiensi pengelolaan obyek wisata menggunakan software Win4DEAP. Metode AHP, IFAS, EFAS, Matriks IE, dan Matriks Space merupakan satu rangkaian untuk menentukan strategi yang digunakan. Keseluruhan hasil analisis yang telah dilakukan kemudian dikombinasikan dengan analisis menggunakan metode A'WOT untuk memberikan arahan pengembangan pariwisata berkelanjutan Kabupaten Wonogiri.

\section{PEMBAHASAN \\ Perkembangan Wilayah Kabupaten Wonogiri}

Hasil perhitungan indeks entropi menunjukkan bahwa nilai entropi total dari Kabupaten Wonogiri pada tahun 2012 adalah sebesar 4,540. Nilai entropi tersebut belum mencapai nilai entropi maksimum karena dengan sembilan komponen pada 25 wilayah kecamatan seharusnya dapat dicapai nilai entropi maksimum sebesar $\ln (9 \times 25)=5,416$. Berdasarkan analisis entropi perkembangan wilayah (Stot/Smaks) dapat diketahui nilai entropi Kabupaten Wonogiri sebesar 0,8382. Hal itu berarti Kabupaten Wonogiri memiliki tingkat perkembangan sebesar $84 \%$ dari total kemampuan maksimumnya sebagaimana dapat dilihat pada Tabel 1.

Tabel 1. Perkembangan Wilayah Kabupaten Wonogiri

\begin{tabular}{l|l|l|l}
\hline \multicolumn{1}{c|}{ Kecamatan } & Jumlah Xi & \multicolumn{1}{|c|}{$\begin{array}{c}\text { Sumbangan PDRB Kecamatan } \\
\text { Terhadap Total PDRB Kabupaten }\end{array}$} & $\begin{array}{c}\text { Peringkat Perkembangan } \\
\text { Kecamatan }\end{array}$ \\
\hline Pracimantoro & 0.2507760 & 5.523603273 & 3 \\
\hline Paranggupito & 0.1041376 & 2.293739080 & 25 \\
\hline Giritontro & 0.1084851 & 2.389498387 & 23 \\
\hline Giriwoyo & 0.1801006 & 3.966903076 & 11 \\
\hline Batuwarno & 0.1057015 & 2.328186083 & 24 \\
\hline Karangtengah & 0.1463813 & 3.224199999 & 17 \\
\hline Tirtomoyo & 0.2163332 & 4.764964385 & 6 \\
\hline Nguntoronadi & 0.1265579 & 2.787568557 & 20 \\
\hline Baturetno & 0.2184985 & 4.812657989 & 5 \\
\hline Eromoko & 0.1974464 & 4.348961901 & 8 \\
\hline Wuryantoro & 0.1601038 & 3.526452295 & 14 \\
\hline Manyaran & 0.1907632 & 4.201757311 & 10 \\
\hline
\end{tabular}




\begin{tabular}{|c|c|c|c|}
\hline Kecamatan & Jumlah Xi & $\begin{array}{l}\text { Sumbangan PDRB Kecamatan } \\
\text { Terhadap Total PDRB Kabupaten }\end{array}$ & \begin{tabular}{|c|}
$\begin{array}{c}\text { Peringkat Perkembangan } \\
\text { Kecamatan }\end{array}$ \\
\end{tabular} \\
\hline Selogiri & 0.1665951 & 3.669430094 & 13 \\
\hline Wonogiri & 0.4335242 & 9.548821213 & 1 \\
\hline Ngadirojo & 0.3087095 & 6.799649092 & 2 \\
\hline Sidoharjo & 0.1975369 & 4.350955226 & 7 \\
\hline Jatiroto & 0.1379081 & 3.037568614 & 19 \\
\hline Kismantoro & 0.1361000 & 2.997743726 & 18 \\
\hline Purwantoro & 0.1935433 & 4.262993768 & 9 \\
\hline Bulukerto & 0.1472464 & 3.243254464 & 16 \\
\hline Puhpelem & 0.1211020 & 2.667398234 & 22 \\
\hline Slogohimo & 0.1624826 & 3.578847445 & 15 \\
\hline Jatisrono & 0.2363821 & 5.206561669 & 4 \\
\hline Jatipurno & 0.1230160 & 2.709554674 & 21 \\
\hline Girimarto & 0.1706493 & 3.758729446 & 12 \\
\hline Jumlah Xj & 4.5400804 & & \\
\hline \multicolumn{4}{|c|}{ Entropi / Tingkat Perkembangan } \\
\hline \multicolumn{3}{|c|}{ Entropi Total (S Tot) } & 4.540080368 \\
\hline \multicolumn{3}{|c|}{ Entropi Maksimum (S Max) } & 5.416100402 \\
\hline \multicolumn{4}{|c|}{ Perkembangan Wilayah } \\
\hline \multicolumn{3}{|c|}{ S Total/S Max } & 0.838256316 \\
\hline
\end{tabular}

Sumber: Pengolahan Data BPS Kabupaten Wonogiri, 2014

Secara berurutan 5 (lima) kecamatan dengan perkembangan wilayah terbaik adalah Kecamatan Wonogiri, Kecamatan Ngadirojo, Kecamatan Pracimantoro, Kecamatan Jatisrono, dan Kecamatan Baturetno. Perkembangan tersebut memicu munculnya kota kecamatan sebagai titik pertumbuhan. Kota kecamatan lain yang tumbuh dengan pesat adalah kota kecamatan Slogohimo dan kota kecamatan Purwantoro. Tumbuhnya ketujuh kota kecamatan utama tersebut didukung adanya jalan nasional dan jalan provinsi dengan kondisi baik yang melewati wilayah tersebut, keberadaan terminal bis antarkota, pasar umum, dan pasar hewan yang produktif.

Kota Kecamatan Wonogiri sebagai Ibukota Kabupaten serta empat kota kecamatan lainnya kecuali Kecamatan Pracimantoro dan Kecamatan Baturetno membentang pada wilayah utara Kabupaten Wonogiri. Secara spesifik obyek-obyek wisata yang berada pada wilayah ibukota dan wilayah utara memiliki keuntungan lebih besar untuk berkembang.

\section{Potensi Obyek-Obyek Wisata Kabupaten Wonogiri}

Kabupaten Wonogiri memiliki beragam obyek wisata yang dapat dikelompokkan kedalam wisata alam, wisata budaya dan wisata minat khusus. Berdasarkan metode skoring yang dilakukan dapat diketahui bahwa 5 (lima) obyek wisata memiliki kelas berpotensi, yaitu : Sendang Asri, Karamba Apung Cakaran, Kawasan Setren Girimanik, Desa Wisata Wayang Kepuhsari dan Kawasan Museum Karst. Ada 15 (lima belas) obyek wisata memiliki kelas cukup berpotensi, yaitu Pantai Sembukan, Pantai Nampu, Pantai Pringjono, Sendang Beton, Goa Putri Kencono, Goa-Waduk Song Putri, Waduk Nawangan, Waduk Ngancar, Khayangan Dlepih, Sendang Siwani, Air Terjun Watusongo, Gunung Gandul, Plinteng Semar, Hutan-Desa Wisata Bubakan, Air 
Terjun Watujadah. Adapun sebanyak 16 (enam belas) obyek wisata lain memiliki kelas kurang berpotensi.

Obyek-obyek wisata dengan klasifikasi berpotensi dapat diposisikan sebagai obyek wisata utama dalam sebuah kawasan wisata sedangkan obyek-obyek wisata dengan klasifikasi cukup berpotensi dapat diposisikan sebagai obyek wisata pendamping. Selengkapnya dapat dilihat pada Peta Sebaran dan Potensi Obyek Wisata di Kabupaten Wonogiri.
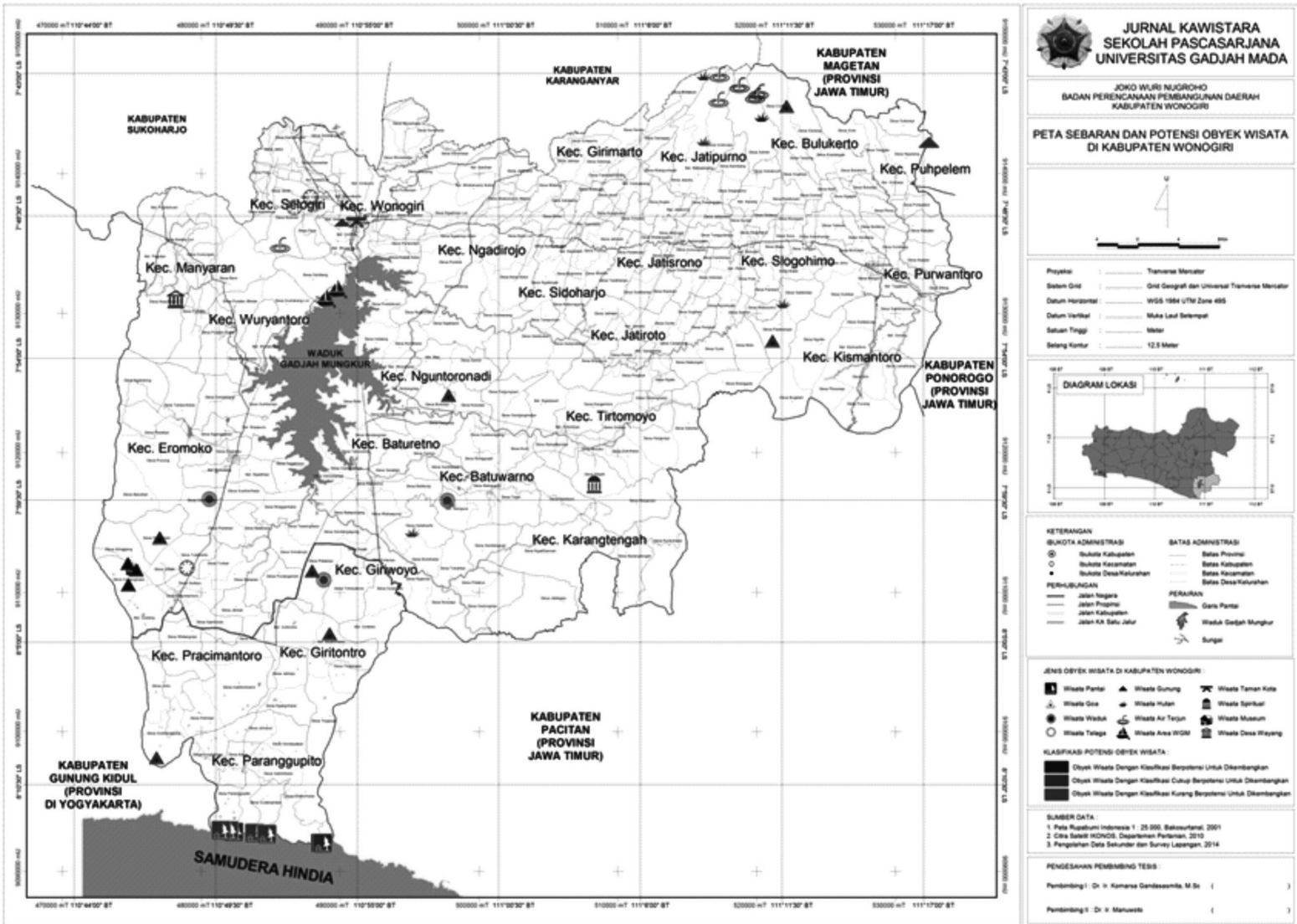

\section{Efisiensi Pengelolaan Obyek-Obyek Wisata Kabupaten Wonogiri}

Hanya ada 7 (tujuh) obyek wisata di Kabupaten Wonogiri yang dikelola sampai saat ini, yaitu Sendang Asri Waduk Gadjah Mungkur,KarambaApungCakaran,Kawasan Setren Girimanik, Khayangan Dlepih, Goa Putri Kencono, Kawasan Museum Karst, dan Pantai Sembukan. Tingkat efisiensi ketujuh obyek wisata tersebut dapat dievaluasi dengan metode DEA melalui software WinDEAP. Menurut Fauzi (2014), Data Envelopment Analysis (DEA) dikembangkan sebagai model dalam pengukuran tingkat kinerja atau produktivitas dari sekelompok unit organisasi. Pengukuran dilakukan untuk mengetahui kemungkinan-kemungkinan penggunaan sumberdaya yang dapat dilakukan untuk menghasilkan output yang optimal. Pada perhitungan analisis ini digunakan 1(satu) variabel output yaitu setoran pendapatan, dan 3 (tiga) variabel input yaitu Jumlah Tenaga Kerja, Harga Tiket, dan Jumlah Pengunjung.

Nilai DMU (pengelolaan obyek wisata) dikatakan efisien bila nilainya sama dengan $1(100 \%)$. Sebaliknya bila nilainya kurang dari 1(satu), maka dikatakan kurang efisien. Perhitungan dengan DEA dengan orientasi Input dan asumsi Constant Return to Scale menunjukkan pengelolaan obyek wisata yang efisien yaitu Sendang Asri Waduk 
Gadjah Mungkur dengan nilai 100\%. Dengan efisiensi yang mencapai 100\% maka Sendang Asri Waduk Gadjah Mungkur tersebut menjadi tolak ukur (benchmark) terhadap obyek wisata lain.

Perhitungan dengan DEA dengan orientasi Input dan asumsi Variabel Return to Scale menunjukkan: (1) pendapatan yang diterima Sendang Asri Waduk Gadjah Mungkur, Kawasan Setren Girimanik, dan Kawasan Museum Karst sudah maksimal sedangkan obyek wisata lain belum maksimal. Untuk Karamba Apung Cakaran dengan pendapatan riil Rp 2.579.000,00 perhitungan maksimalnya adalah Rp 9.007. 650,00 Untuk Khayangan Dlepih dengan pendapatan riil Rp19.510.000,00 perhitungan maksimalnya adalah Rp 82.451.525,00. Untuk Goa Putri Kencono dengan pendapatan riil $\mathrm{Rp} 3.385$. 000,00 perhitungan maksimalnya adalah Rp 12.879. 350,00. Untuk Pantai Sembukan dengan pendapatan riil Rp18.911.000,00 perhitungan maksimalnya adalah Rp79.915. 150,00. (2) memperhitungkan jumlah pengunjung serta pendapatan yang diterima, maka jumlah tenaga kerja yang efisien hanya pada obyek wisata Sendang Asri Waduk Gadjah Mungkur. Untuk Karamba Apung Cakaran dan Goa Putri Kencono tenaga kerja lebih tepat diberikan kepada masyarakat setempat. Untuk Kawasan Setren Girimanik dari 3 (tiga) tenaga kerja dikurangi menjadi 2 (dua) tenaga kerja; Khayangan Dlepih dari 3 (tiga) tenaga kerja dikurangi menjadi 1 (satu) tenaga kerja; Kawasan Museum Karst dari 7 (tujuh) tenaga kerja dikurangi menjadi 4 (empat) tenaga kerja; Pantai Sembukan dari 3 (tiga) tenaga kerja dikurangi menjadi 1(satu) tenaga kerja.

Perhitungan dengan DEA dengan orientasi Output dan asumsi Constant Return to Scale maupun orientasi Output dan asumsi Variabel Return to Scale menunjukkan kecuali obyek wisata Sendang Asri Waduk Gadjah Mungkur apabila dilakukan penambahan terhadap input akan memberikan pengaruh terhadap output yang akan dihasilkannya.

\section{Perbedaan Pengelolaan Kepariwisataan Kabupaten Wonogiri Dengan Kabupaten Gunungkidul dan Kabupaten Pacitan}

Berdasarkan hasil survey yang dilakukan, terdapat perbedaan kebijakan kepariwisataan antara Kabupaten Wonogiri dengan Kabupaten Gunungkidul dan Kabupaten Pacitan sebagaimana dapat dilihat pada Tabel 2.

Tabel 2

Perbedaan Pengelolaan Kepariwisataan Kabupaten Wonogiri Kabupaten Gunungkidul Dan Kabupaten Pacitan

\begin{tabular}{|c|c|c|c|c|}
\hline No & Keterangan & Kabupaten Gunungkidul & Kabupaten Pacitan & Kabupaten Wonogiri \\
\hline 1 & $\begin{array}{l}\text { Aksesibilitas } \\
\text { menuju obyek } \\
\text { wisata }\end{array}$ & $\begin{array}{l}\text { Aksesibilitas sangat } \\
\text { baik. Penataan } \\
\text { akses jalan sangat } \\
\text { memudahkan } \\
\text { perjalanan wisatawan }\end{array}$ & $\begin{array}{l}\text { Aksesibilitas sebenarnya } \\
\text { sangat baik. Akan tetapi } \\
\text { strategi penataan akses } \\
\text { beberapa obyek wisata } \\
\text { jalan kurang maksimal } \\
\text { sehingga terjadi macet }\end{array}$ & $\begin{array}{l}\text { Aksesibilitas kurang } \\
\text { baik. Kondisi jaringan } \\
\text { jalan banyak yang } \\
\text { sudah rusak }\end{array}$ \\
\hline 2 & $\begin{array}{l}\text { Keberadaan } \\
\text { sarana prasarana } \\
\text { pelengkap dan } \\
\text { pendukung } \\
\text { obyek wisata }\end{array}$ & $\begin{array}{l}\text { Terpenuhi secara } \\
\text { maksimal }\end{array}$ & Memadai & $\begin{array}{l}\text { Kebanyakan kurang } \\
\text { memadai }\end{array}$ \\
\hline 3 & $\begin{array}{l}\text { Kealamian } \\
\text { obyek wisata } \\
\text { yang dimiliki }\end{array}$ & $\begin{array}{l}\text { Selalu berusaha } \\
\text { untuk dipertahankan } \\
\text { kealamiannya }\end{array}$ & $\begin{array}{l}\text { Penambahan fasilitas } \\
\text { yang justru mengurangi } \\
\text { kealamian obyek wisata }\end{array}$ & $\begin{array}{l}\text { Penambahan fasilitas } \\
\text { yang justru mengurangi } \\
\text { kealamian obyek wisata }\end{array}$ \\
\hline 4 & $\begin{array}{l}\text { Partisipasi } \\
\text { Masyarakat }\end{array}$ & Aktif & Pasif & Pasif \\
\hline
\end{tabular}




\begin{tabular}{l|l|l|l|l}
\hline No & Keterangan & Kabupaten Gunungkidul & Kabupaten Pacitan & Kabupaten Wonogiri \\
\hline 5 & Tiket masuk & $\begin{array}{l}\text { Terjangkau. Tiket } \\
\text { masuk obyek wisata } \\
\text { dalam satu kawasan } \\
\text { terintegrasi }\end{array}$ & Terjangkau & Terjangkau \\
\hline 6 & $\begin{array}{l}\text { Promosi Melalui } \\
\text { Media Sosial }\end{array}$ & $\begin{array}{l}\text { Dilakukan secara } \\
\text { maksimal }\end{array}$ & $\begin{array}{l}\text { Mulai dilakukan secara } \\
\text { maksimal }\end{array}$ & $\begin{array}{l}\text { Belum dilakukan secara } \\
\text { maksimal }\end{array}$ \\
\hline
\end{tabular}

Sumber: Observasi Lapangan (2014)

Hal menarik yang ditemukan di Kabupaten Gunungkidul adalah partisipasi aktif masyarakat dalam pengembangan pariwisata suatu kawasan obyek. Hal ini menimbulkan respon balik positif dari masyarakat yang mendukung kepariwisataan. Partisipasi masyarakat sangat menentukan karena merekalah yang secara langsung melekat terhadap dinamika kepariwisataan baik berhubungan dengan obyek wisata maupun wisatawannya; Tiket masuk obyek wisata dalam satu kawasan selain cukup terjangkau juga terintegrasi dalam satu pintu masuk; dan pintu keluar. Wisatawan hanya membayar tiket satu kali untuk dapat menikmati obyek dalam satu kawasan. Pemerintah daerah lebih membidik pendapatan di luar tiket masuk hasil dari multiplier efek sektor lain yang terkait pariwisata, misalnya dari parkir, retribusi warung atau rumah makan yang dikelola masyarakat, penginapan/hotel, dan sebagainya.
Dari tabel di atas terlihat bahwa pengelolaan kepariwisataan Kabupaten Gunungkidul lebih ideal dibandingkan dengan Kabupaten Pacitan untuk digunakan sebagai bahan bagi arahan pengembangan pariwisata berkelanjutan di Kabupaten Wonogiri untuk menyempurnakan Kebijakan Pengembangan Pariwisata yang telah digunakan pada saat ini.

\section{Strategi Pengembangan Pariwisata Kabupaten Wonogiri}

Strategi pengembangan kepariwisataan di Kabupaten Wonogiri dapat diperoleh melalui penggunaan beberapa metode analisis, meliputi Metode AHP, Metode IFAS, Metode EFAS, Metode Matriks IE dan Metode Matriks Space. Adapun langkahlangkah yang diperlukan sebagai berikut ini.

a. Pembuatan hierarki dan penilaian strategi melalui analisis AHP

Hierarki strategi pengembangan obyek wisata di Kabupaten Wonogiri disusun terlihat pada Gambar 1.

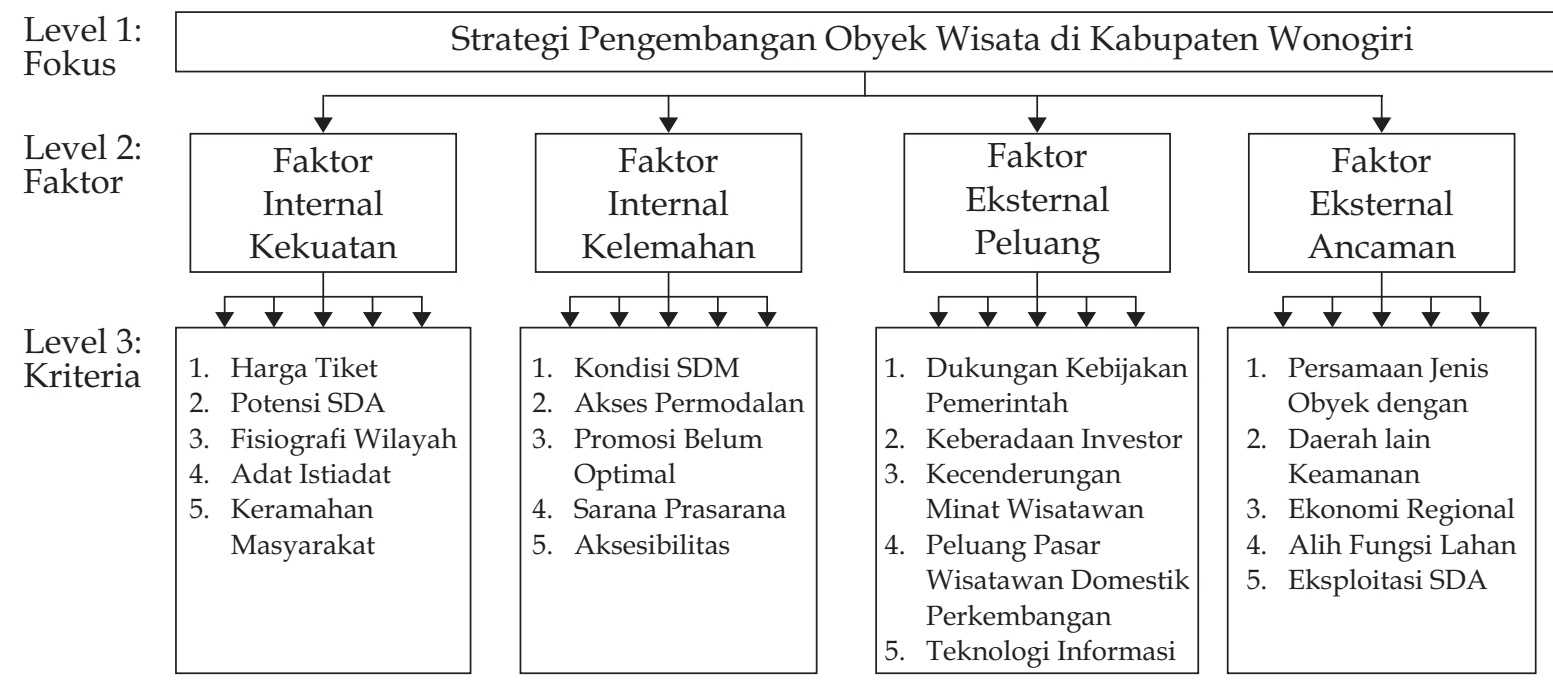

Gambar 1

Struktur Hierarki Strategi Pengembangan Pariwisata Kabupaten Wonogiri 
Dari penilaian yang diberikan responden ahli kemudian dilakukan analisis dengan metode AHP untuk mendapatkan nilai kuantitatif dari masing-masing faktor strategi internal dan eksternal yang ditunjukkan pada Tabel 3.

Tabel 3.

Perhitungan Analytical Hierarchy Process (AHP)

\begin{tabular}{l|l|l}
\hline \multicolumn{1}{c|}{ Faktor-Faktor Strategi } & \multicolumn{1}{c}{ Nilai $^{*}$} & Bobot (Nilai x 0,5) \\
\hline Faktor Internal : & & \\
\hline Kekuatan & & \\
\hline 1. Harga Tiket & 0.067 & 0.033 \\
\hline 2. Potensi SDA & 0.408 & 0.204 \\
\hline 3. Fisiografis Wilayah & 0.154 & 0.077 \\
\hline 4. Adat Istiadat (Keramahan Masyarakat) & 0.153 & 0.076 \\
\hline 5. Dukungan Masyarakat & 0.219 & 0.109 \\
\hline Kelemahan & & \\
\hline 1. Kondisi SDM & 0.224 & 0.112 \\
\hline 2. Akses Permodalan & 0.096 & 0.048 \\
\hline 3. Promosi Belum Optimal & 0.114 & 0.057 \\
\hline 4. Sarana dan Prasarana & 0.261 & 0.130 \\
\hline 5. Aksesibilitas & 0.306 & 0.153 \\
\hline Faktor Eksternal : & & \\
\hline Peluang & & \\
\hline 1. Dukungan Kebijakan Pemerintah & 0.270 & 0.135 \\
\hline 2. Keberadaan Investor & 0.161 & 0.081 \\
\hline 3. Kecenderungan Minat Wisatawan (wisata alam dan tradisional) & 0.265 & 0.133 \\
\hline 4. Peluang Pasar Wisatawan Domestik & 0.187 & 0.093 \\
\hline 5. Perkembangan Teknologi Informasi & 0.116 & 0.058 \\
\hline Ancaman & & \\
\hline 1. Persamaan Jenis Obyek dengan Daerah Lain & 0.210 & 0.105 \\
\hline 2. Keamanan & 0.211 & 0.106 \\
\hline 3. Ekonomi Regional & 0.199 & 0.100 \\
\hline 4. Alih Fungsi Lahan & 0.197 & 0.098 \\
\hline 5. Eksploitasi SDA & 0.183 & 0.092 \\
\hline Sber & &
\end{tabular}

Sumber : Hasil Analisis Data (2014)

b. Analisis Faktor Strategi Internal dan Eksternal

Setelah didapatkan nilai bobot faktorfaktor strategi internal (kekuatan dan kelemahan) dan eksternal (peluang dan ancaman), selanjutnya dilakukan penyusunan matriks Internal Strategic Faktors Analysis Summary (IFAS) dan External Strategic Faktors Analysis Summary (EFAS) sebagaimana tersaji pada Tabel 4 dan Tabel 5.

Tabel 4

IFAS Pengembangan Obyek Wisata di Kabupaten Wonogiri

\begin{tabular}{l|l|l|c}
\hline \multicolumn{1}{c|}{ Faktor-Faktor Strategi Internal } & Bobot & Rating & \multicolumn{1}{c}{ Skor } \\
\hline Kekuatan & & & \\
\hline 1. Harga Tiket & 0.033 & 2 & 0.067 \\
\hline 2. Potensi SDA & 0.204 & 4 & 0.816 \\
\hline 3. Fisiografis Wilayah & 0.077 & 3 & 0.231 \\
\hline 4. Adat Istiadat (Keramahan Masyarakat) & 0.076 & 3 & 0.229 \\
\hline
\end{tabular}


Lanjutan Tabel 4.

\begin{tabular}{l|l|l|c}
\hline \multicolumn{1}{c|}{ Faktor-Faktor Strategi Internal } & Bobot & Rating & \multicolumn{1}{c}{ Skor } \\
\hline 5. Dukungan Masyarakat & 0.109 & 3 & 0.328 \\
\hline Kelemahan & & & \\
\hline 1. Kondisi SDM & 0.112 & 3 & 0.335 \\
\hline 2. Akses Permodalan & 0.048 & 2 & 0.096 \\
\hline 3. Promosi Belum Optimal & 0.057 & 2 & 0.114 \\
\hline 4. Sarana dan Prasarana & 0.130 & 3 & 0.391 \\
\hline 5. Aksesibilitas & 0.153 & 3 & 0.458 \\
\hline & & & \\
\hline TOTAL & 1.000 & & 3.066 \\
\hline
\end{tabular}

Sumber: Hasil Analisis Data (2014)

Tabel 5

EFAS Pengembangan Obyek Wisata di Kabupaten Wonogiri

\begin{tabular}{l|l|l|l}
\hline \multicolumn{1}{c|}{ Faktor-Faktor Strategi Eksternal } & \multicolumn{1}{c}{ Bobot } & Rating & \multicolumn{1}{c}{ Skor } \\
\hline Peluang & & & \\
\hline 1. Dukungan Kebijakan Pemerintah & 0.135 & 3 & 0.405 \\
\hline 2. Keberadaan Investor & 0.081 & 2 & 0.161 \\
\hline 3. Kecenderungan Minat Wisatawan (wisata alam dan tradisional) & 0.133 & 3 & 0.398 \\
\hline 4. Peluang Pasar Wisatawan Domestik & 0.093 & 3 & 0.280 \\
\hline 5. Perkembangan Teknologi Informasi & 0.058 & 2 & 0.116 \\
\hline Ancaman & & & \\
\hline 1. Persamaan Jenis Obyek dengan Daerah Lain & 0.105 & 2 & 0.210 \\
\hline 2. Keamanan & 0.106 & 2 & 0.211 \\
\hline 3. Ekonomi Regional & 0.100 & 3 & 0.299 \\
\hline 4. Alih Fungsi Lahan & 0.098 & 3 & 0.295 \\
\hline 5. Eksploitasi SDA & 0.092 & 3 & 0.275 \\
\hline & & & \\
\hline
\end{tabular}

Sumber : Hasil Analisis (2014)

Nilai yang diperoleh dari Internal Strategic Faktors Analysis Summary (IFAS) dan External Strategic Faktors Analysis Summary (EFAS) seperti terlihat pada Tabel 4 dan Tabel 5 akan diteruskan untuk melakukan analisis matriks internal-eksternal (Matriks IE) dan analisis matriks space.

c. Analisis Matriks Internal - Eksternal (Matriks IE)

Analisis matriks internal-eksternal

(IE) digunakan untuk memperoleh strategi yang lebih detail. Berdasarkan hasil analisis faktor strategi internal dan analisis faktor strategi eksternal, diperoleh nilai total skor faktor internal sebesar 3,066 dan nilai total skor faktor eksternal sebesar 2,650. Apabila masing-masing parameter ini dipetakan ke dalam matriks IE, maka pengembangan obyek wisata di Kabupaten Wonogiri berada pada sel 4 seperti terlihat pada Gambar 2. 


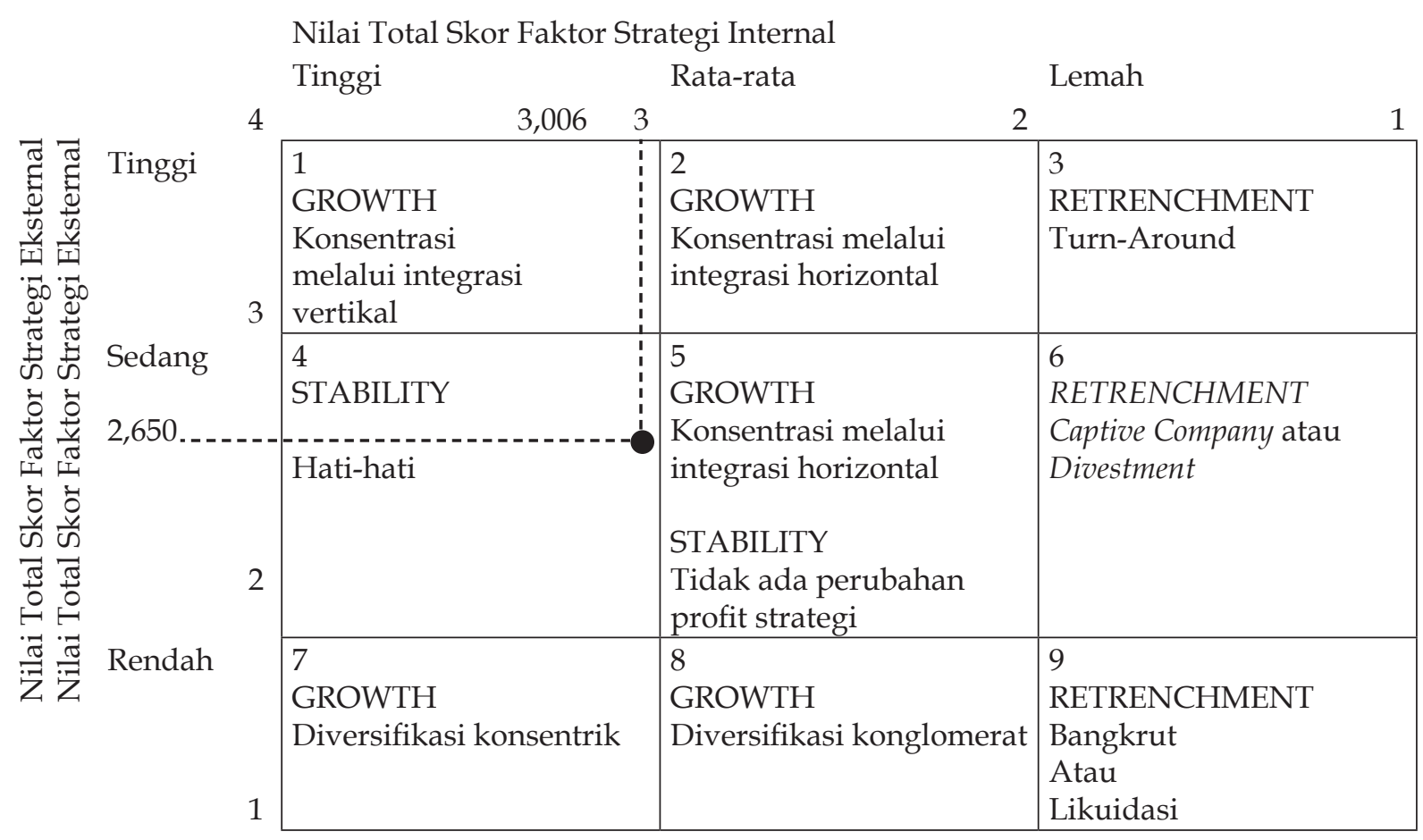

Gambar 2 Matriks Internal-Eksternal (Matriks IE)

Sumber: Diadaptasi dari Rangkuti (2009)

Gambar di atas menunjukkan bahwa strategi pengembangan pariwisata yang diperlukan di Kabupaten Wonogiri adalah strategi yang tidak merubah secara total strategi/kebijakan sebelumnya namun melakukan perbaikan secara perlahan dan memperhatikan unsur kehati-hatian dalam pengelolaan pariwisata yang ada.

d. Analisis Matriks Space

Hasil analisis matriks space dapat digunakan untuk mempertajam strategi yang akan dikembangkan. Parameter yang digunakan dari hasil analisis faktor strategi internal dan analisis faktor strategi eksternal, yaitu selisih dari skor internal (kekuatan - kelemahan) dan selisih dari skor faktor eksternal (peluang - ancaman) dengan perhitungan sebagai berikut:

kekuatan - kelemahan $=1,671-1,395=0,276$

peluang - ancaman $=1,361-1,289=0,072$

\begin{tabular}{|c|c|c|c|}
\hline \multirow{3}{*}{$\begin{array}{l}\text { Kelemahan } \\
\text { Internal }\end{array}$} & \multicolumn{2}{|c|}{ Berbagai Peluang } & \\
\hline & $\begin{array}{l}\text { Kuadran III } \\
\text { Strategi Turn- } \\
\text { Around }\end{array}$ & $\begin{array}{c}\text { Kuadran I } \\
\text { Strategi Agresif } \\
(0,276 ; 0,072)\end{array}$ & \multirow{3}{*}{$\begin{array}{c}\text { Kekuatan } \\
\text { Internal }\end{array}$} \\
\hline & & 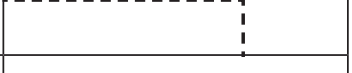 & \\
\hline & $\begin{array}{l}\text { Strategi Defensif } \\
\text { Kuadran IV }\end{array}$ & \begin{tabular}{|c} 
Strategi Diversifikasi \\
Kuadran II
\end{tabular} & \\
\hline & Berbag & Ancaman & \\
\hline
\end{tabular}

Gambar 3 Hasil Analisis Matriks Space

Sumber: Diadaptasi dari Rangkuti (2009) 
Hasil analisis menunjukkan bahwa strategi pengembangan obyek wisata di Kabupaten Wonogiri berada di kuadran I, yaitu melalui strategi agresif. Posisi ini menguntungkan, di mana Kabupaten Wonogiri dapat terus mengembangkan potensi pariwisata yang dimilikinya karena memiliki kekuatan untuk dapat menangkap dan memanfaatkan peluang yang ada.

\section{Arahan Pengembangan Pariwisata Berkelanjutan Kabupaten Wonogiri}

Langkah pertama untuk memberikan Arahan Pengembangan Kawasan Wisata Berkelanjutan adalah melakukan analisis menggunakan metode A'WOT. Metode A'WOT ini menggabungkan nilai bobot yang telah diperoleh dari analisis AHP yang telah dilakukan untuk dipadukan dengan desain analisis Kekuatan, Kelemahan, Peluang dan Ancaman (SWOT) sebagaimana dapat dilihat pada Gambar 4.

\begin{tabular}{|c|c|c|}
\hline Faktor Eksternal & 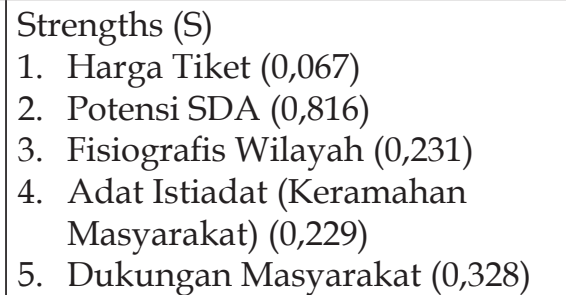 & $\begin{array}{l}\text { Weaknesses }(W) \\
\text { 1. Kondisi SDM }(0,335) \\
\text { 2. Akses Permodalan }(0,096) \\
\text { 3. Promosi Belum Opimal }(0,114) \\
\text { 4. Sarana dan Prasarana }(0,391) \\
\text { 5. Aksesibilitas }(0,458)\end{array}$ \\
\hline $\begin{array}{l}\text { Opportunities }(\mathrm{O}) \\
\text { 1. } \\
\text { Dukungan Kebijakan } \\
\text { Pemerintah }(0,405) \\
\text { 2. } \text { Keberadaan Investor } \\
(0,161) \\
\text { 3. Kecenderungan } \\
\text { MinatWisatawan } \\
\text { (wisata alam dan } \\
\text { tradisional) }(0,398) \\
\text { 4. Peluang Pasar Wisata- } \\
\text { wan Domestik }(0,280) \\
\text { 5. Perkembangan } \\
\text { Teknologi Informasi } \\
(0,116)\end{array}$ & 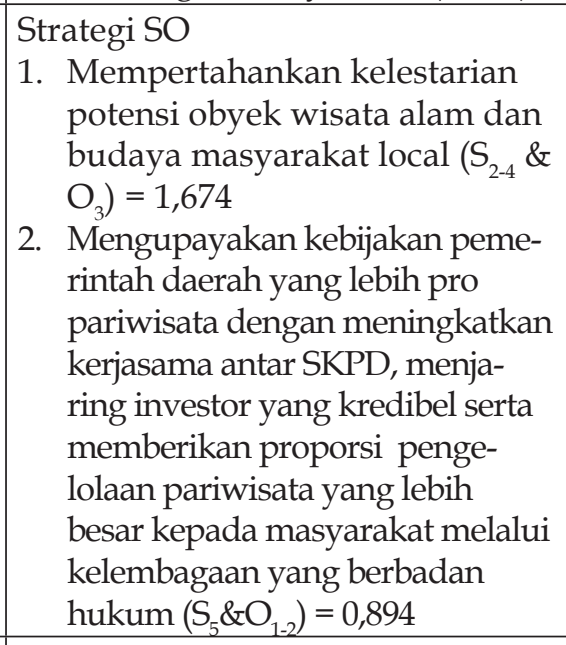 & $\begin{array}{l}\text { Strategi WO } \\
\text { 1. Memaksimalkan peran } \\
\text { pemerintah daerah dalam } \\
\text { meningkatkan kuantitas dan } \\
\text { kualitas aksesibilitas, sarana } \\
\text { prasarana serta kondisi SDM } \\
\text { terkait pariwisata sesuai dengan } \\
\text { kearifan local masyarakat }\left(\mathrm{W}_{1,4-}\right. \\
\left.{ }_{5} \& \mathrm{O}_{1}\right)=1,589 \\
\text { 2. Mengoptimalkan promosi } \\
\text { melalui teknologi informasi } \\
\text { dalam menjaring wisatawan } \\
\text { lokal }\left(\mathrm{W}_{3} \& \mathrm{O}_{4-5}\right)=0,510\end{array}$ \\
\hline $\begin{array}{l}\text { Treaths }(\mathrm{T}) \\
\text { 1. Persamaan Jenis } \\
\text { Obyek Dengan Daerah } \\
\text { Lain }(0,210) \\
\text { 2. Keamanan }(0,211) \\
\text { 3. Ekonomi Regional } \\
\quad(0,299) \\
\text { 4. Alih Fungsi Lahan } \\
\text { (0,295) } \\
\text { 5. Eksploitasi SDA }(0,275)\end{array}$ & \begin{tabular}{|l} 
Strategi ST \\
1. Mempertahankan kelestarian \\
potensi obyek wisata serta me- \\
ningkatkan kerjasama dengan \\
kabupaten tetangga dengan \\
prinsip saling menguntungkan \\
$\left(\mathrm{S}_{1-3} \& \mathrm{~T}_{1}\right)=1,324$ \\
2. \\
Mengupayakan dukungan \\
masyarakat untuk memini- \\
malisir gangguan kemanan \\
yang dapat berdampak ter- \\
hadap stabilitas ekonomi regio- \\
nal serta kerusakan lingkungan \\
akibat dampak pariwisata \\
$\left(\mathrm{S}_{4-5} \& \mathrm{~T}_{2-5}\right)=1,375$
\end{tabular} & 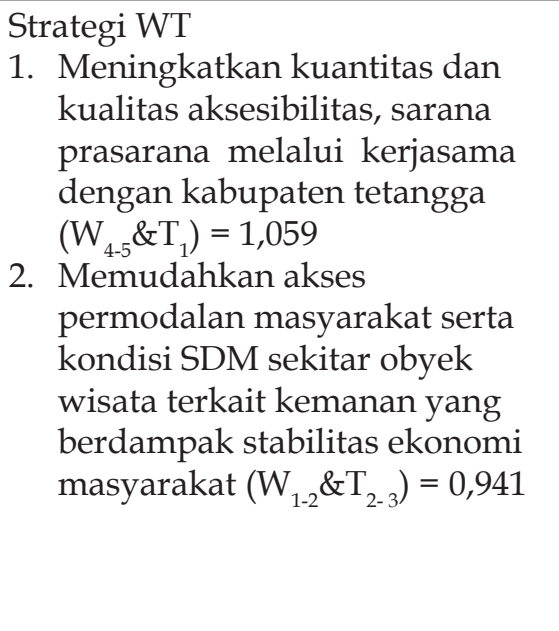 \\
\hline
\end{tabular}

Gambar 4 Hasil Analisis Matriks SWOT 
Terdapat empat kawasan utama yang dapat dikembangkan diKabupaten Wonogiri, yaitu kawasan wisata ibukota, kawasan wisata utara, kawasan wisata tengah, dan kawasan wisata selatan, sebagaimana dapat dilihat pada Tabel 6 .

Tabel 6 Kawasan Wisata Kabupaten Wonogiri

\begin{tabular}{|c|c|c|c|c|}
\hline No & $\begin{array}{c}\text { Kawasan } \\
\text { Wisata }\end{array}$ & $\begin{array}{c}\text { Obyek Wisata Utama } \\
\text { dan Lokasi Tiket Masuk } \\
\text { Terintegrasi }\end{array}$ & Obyek Wisata Pendamping & $\begin{array}{c}\text { Sektor yang } \\
\text { Dikembangkan }\end{array}$ \\
\hline 1 & Utara & $\begin{array}{l}\text { Kawasan Setren } \\
\text { Girimanik }\end{array}$ & $\begin{array}{l}\text { Air Terjun Watujadah, } \\
\text { Hutan Seper, Hutan\&Desa } \\
\text { Wisata Bubakan dan Goa } \\
\text { Resi }\end{array}$ & $\begin{array}{l}\text { Sektor pariwisata, } \\
\text { pertanian, perkebunan } \\
\text { dan industri kecil }\end{array}$ \\
\hline 2 & Ibukota & $\begin{array}{l}\text { Sendang Asri Waduk } \\
\text { Gadjah Mungkur }\end{array}$ & $\begin{array}{l}\text { Karamba Cakaran, } \\
\text { Sendang Siwani, Air Terjun } \\
\text { Watusongo, Gunung } \\
\text { Gandul dan Plinteng Semar }\end{array}$ & $\begin{array}{l}\text { Sektor pariwisata, jasa } \\
\text { dan perdagangan }\end{array}$ \\
\hline 3 & Tengah & Museum Karst & $\begin{array}{l}\text { Sendang Beton, Goa Putri } \\
\text { Kencono, Waduk\&Goa } \\
\text { Song Putri dan Desa Wisata } \\
\text { Wayang Kepuhsari }\end{array}$ & $\begin{array}{l}\text { Sektor pariwisata, jasa, } \\
\text { pertanian dan perikanan } \\
\text { darat }\end{array}$ \\
\hline 4 & Selatan & Pantai Nampu & $\begin{array}{l}\text { Pantai Pringjono, Pantai } \\
\text { Sembukan }\end{array}$ & $\begin{array}{l}\text { Sektor pariwisata, } \\
\text { perikanan laut }\end{array}$ \\
\hline
\end{tabular}

Kawasan wisata utara diberikan prioritas teratas untuk pengembangan melalui pendekatan Agrowisata maupun Forestry Tourism mengingat fungsinya sebagai kawasan lindung dan daerah tangkapan air Waduk Gadjah Mungkur sehingga dengan sendirinya menjamin pula kelestarian Kawasan Wisata Ibukota yang banyak bertumpu kepada waduk tersebut. Hal ini dirasakan cukup sejalan dengan Peta Pola Ruang dari Rencana Tata Ruang Kabupaten Wonogiri 2011 - 2031. Adapun Kawasan Tengah dan Kawasan Selatan bisa dikembangkan setelahnya mengingat sulitnya bersaing dengan obyek wisata sejenis yang dimiliki Kabupaten Gunungkidul dan Kabupaten Pacitan. Selengkapnya dapat dilihat pada Peta Kawasan Wisata Kabupaten Wonogiri.

\section{SIMPULAN}

Berdasarkan hasil analisis A'WOT serta analisis-analisis yang telah dilakukan sebelumnya, penelitian ini memberikan implikasi berupa penyempurnaan terhadap kebijakan kepariwisataan yang diterapkan saat ini tanpa melakukan perubahan yang bersifat radikal terhadap kebijakan yang telah ada.

Empat rumusan arahan pengembangan kawasan wisata berkelanjutan di Kabupaten Wonogiri yang ditawarkan sebagai berikut: Pertama, Pembuatan 4 (empat) kawasan wisata. Pembuatan kawasan wisata akan memberikan pilihan yang lebih banyak kepada wisatawan, dapat lebih menonjolkan potensi khas yang dimiliki berupa potensi sumberdaya alam dan tradisi, memudahkan usaha pelestarian mencegah eksploitasi dan kerusakan lingkungan yang berlebihan serta memudahkan pengelolaannya.

Kedua, Mempertimbangkan kondisi kepariwisataan Kabupaten Gunungkidul yang ditopang keunggulan aksesibilitas dan prasarana jalan yang menuju obyek wisata yang dimilikinya serta peranmasyarakat yang besar, maka arahan kebijakan kepariwisataan Kabupaten Wonogiri didorong untuk lebih meningkatkan aksesibilitas dan sarana prasarana wilayah sekitar obyek wisata yang disesuaikan dengan kearifan lokal masyarakat. Sebagai contoh pembangunan jaringan jalan poros desa menuju lokasi obyek wisata lebih tepat dilakukan pembuatan 
rabat jalan dibandingkan pengaspalan jalan. Model rabat jalan lebih mudah dalam pemeliharaannya dibandingkan dengan jalan aspal.

Ketiga, Memberikan kesempatan yang lebih luas bagi masyarakat untuk turut menikmati profit dari keberadaan obyek wisata sehingga dukungan dan partisipasi aktif dari masyarakat lebih bisa diharapkan. Beberapa obyek wisata yang belum atau tidak mampu dikelola oleh pemerintah daerah bisa diserahkan pengelolaannya kepada masyarakat; Meningkatkan kualitas sumberdaya daya manusia yang ter- kait kepariwisataan, akses permodalan masyarakat sekitar obyek wisata, promosi dan penjaringan investor melalui teknologi informasi yang berkembang. Peran serta dan kerjasama antar Satuan Kerja Perangkat Daerah (SKPD) Pemerintah Kabupaten Wonogiri mutlak diperlukan.

Keempat, Usaha memperkuat kerjasama kepariwisataan dengan kabupaten tetangga melalui pembangunan kemitraan dan membentuk jejaring dengan prinsip saling menguntungkan. Forum kerjasama Pawonsari, Karismapawirogo maupun Subosukowonosraten perlu lebih ditingkatkan fungsi dan peranannya.
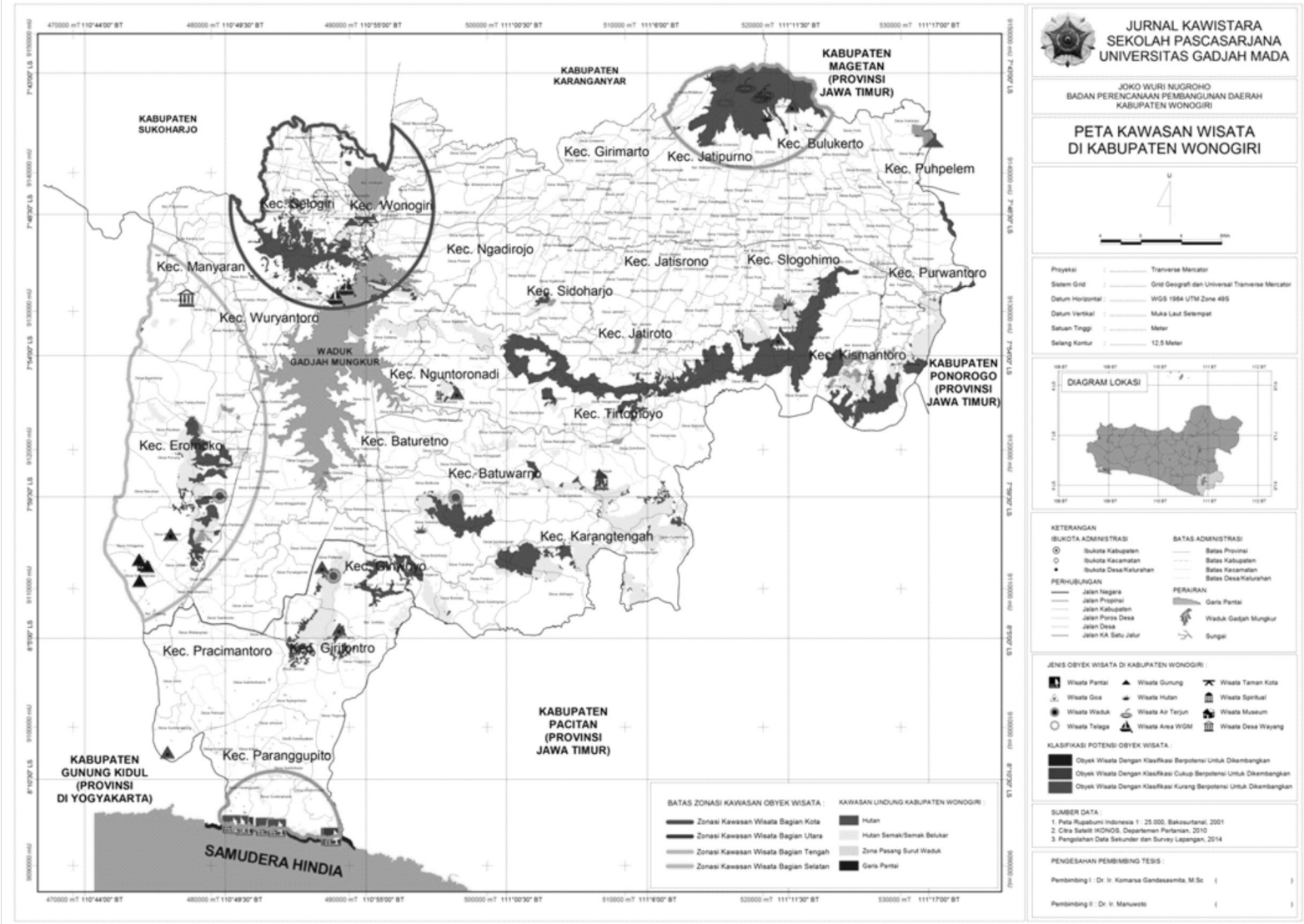

Gambar 5.

Peta Kawasan Wisata di Kabupaten Wonogiri 


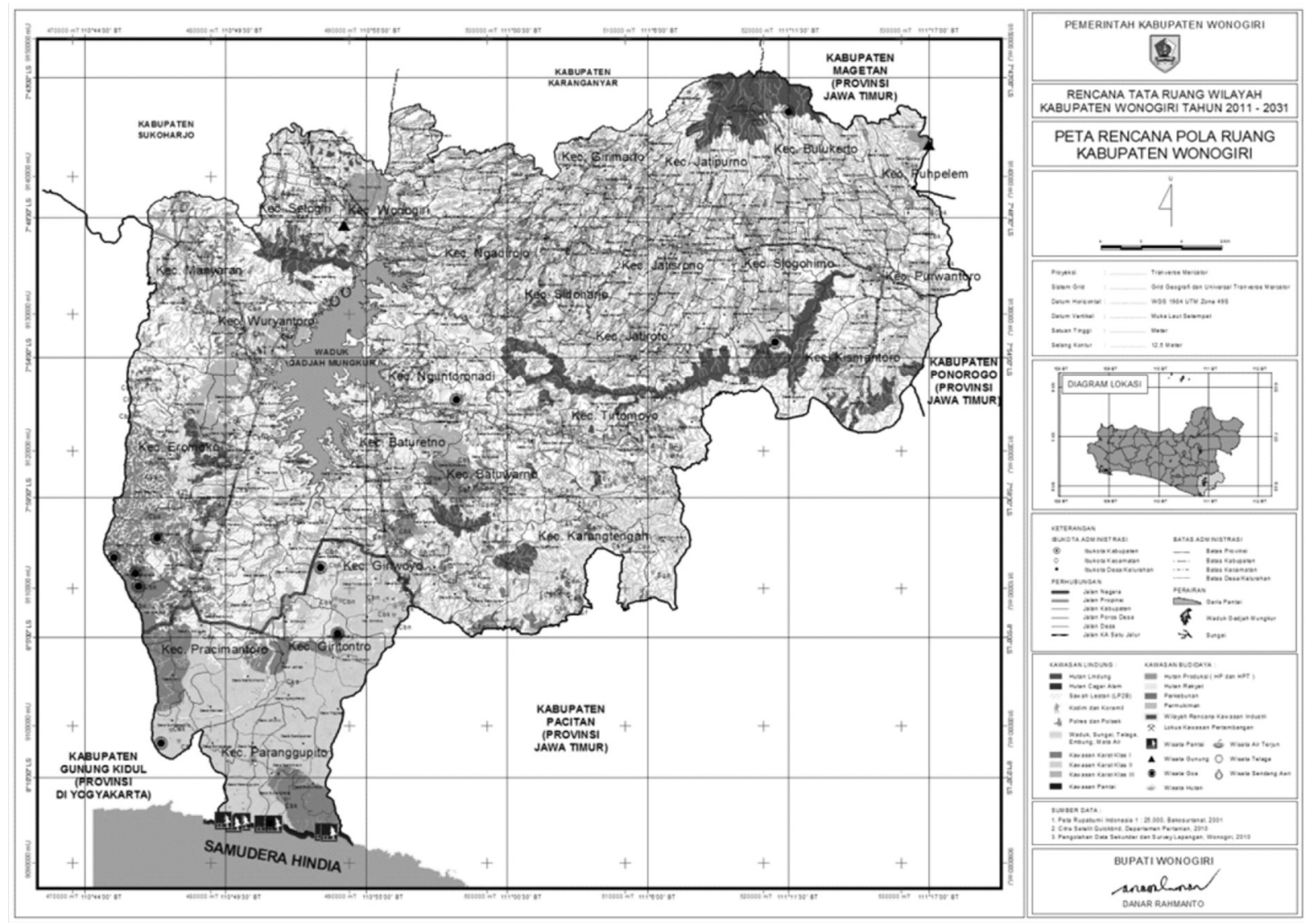

Gambar 6.

Peta Rencana Pola Ruang Kabupaten Wonogiri

\section{DAFTAR PUSTAKA}

Badan Perencanaan Pembangunan Daerah. 2004. Rencana Induk Pengembangan Pariwisata Daerah (RIPPDA) Kabupaten Wonogiri Tahun 2004-2014. Desember. Bappeda Wonogiri. Wonogiri.

Badan Pusat Statistik. 2013. Gunungkidul Dalam Angka Tahun 2013. Desember. BPS Gunungkidul. Wonosari.

Badan Pusat Statistik. 2013. Pacitan Dalam Angka Tahun 2013. Desember.BPS Pacitan. Pacitan.

Badan Pusat Statistik. 2013. Wonogiri Dalam Angka Tahun 2013. Desember. BPS Wonogiri. Wonogiri.

Conyers, D. 1984. An Introduction To Sosial Planning In The Third World (Terjemahan). John Wiley \& Sons Ltd. England.
Dinas Pariwisata. 2012. Statistik Kepariwisataan Tahun 2012.Juni. Dinas Pariwisata Daerah Istimewa Yogyakarta. Yogyakarta.

Fandeli, C. 1995. Dasar-Dasar Manajemen Kepariwisataan Alam. Penerbit Liberty. Yogyakarta.

Fauzi, A. 2014. Teknik Evaluasi Ekonomi Sumberdaya Wilayah. Bahan Kuliah. Institut Pertanian Bogor. Bogor.

Kurniawati, R. 2013. Modul Pariwisata Berkelanjutan. Bappenas. Jakarta.

Muhammad. Fandeli, C. Baiquni, M. 2012. Studi Perkembangan Wilayah dan Daya Dukung Lingkungan Kepariwisataan di Wilayah Yogyakarta Utara. Jurnal Kawistara Volume 2 (1): 15-24.

Rangkuti, F. 2009. Analisis SWOT Teknik Membedah Kasus Bisnis. PT. Gramedia Pustaka Utama. Jakarta. 
Rudita, I.K.P. 2012. Potensi Obyek Wisata dan Keterpaduannya dalam Pengembangan Kawasan Agropolitan Payangan Kabupaten Gianyar Provinsi Bali. Tesis. Sekolah Pasca Sarjana IPB. Bogor.

Saaty, T.L. 1991. Pengambilan Keputusan Bagi Para Pemimpin, Proses Hierarki Analitik untuk Pengambilan Keputusan Dalam Situasi yang Komplek (Terjemahan). PT. Pustaka Binaman Pressindo. Jakarta.

Sitorus, S. 2013. Perencanaan Pengembangan Wilayah. Bahan Kuliah. Institut Pertanian Bogor. Bogor. 